Western North American Naturalist 71(1), (C) 2011, pp. 119-120

\title{
EXTENSION OF SOUTHERN RANGE AND NEW SPECIMENS OF THE WESTERN GRAY SQUIRREL, SCIURUS GRISEUS ANTHONYI (MAMMALIA: SCIURIDAE), IN BAJA CALIFORNIA, MÉXICO
}

\author{
Jonathan Gabriel Escobar-Flores ${ }^{1,2}$, Gorgonio Ruiz-Campos ${ }^{1}$, Aldo Antonio Guevara-Carrizales ${ }^{1}$, \\ and Roberto Martínez-Gallardo ${ }^{1}$
}

\begin{abstract}
We documented a southern range extension and new specimens of western gray squirrel (Sciurus griseus anthonyi) for the state of Baja California, México. The most recent specimen was collected in the town Cataviña and represents the southernmost record for the species and subspecies. Repeated observations of individuals in this new location suggest the presence of a marginal population in Mediterranean chaparral-desert scrub transition vegetation.
\end{abstract}

REsumen.-Documentamos la extension de ámbito más sureño y nuevos especímenes de a ardilla gris occidental (Sciurus griseus anthonyi) para el Estado de Baja California, México. El espécimen más reciente fue recolectado en el poblado de Cataviña y representa el registro más sureño para la especie y subespecie. Observaciones repetidas de individuos en esta última localidad sureña sugiere la presencia de una población marginal en vegetación de transición de chaparral mediterráneo-matorral desértico.

The western gray squirrel (Sciurus griseus), or California squirrel, is found along the western coast of North America with 3 geographical subspecies: Sciurus griseus griseus (central Washington to the western Sierra Nevada in central California), Sciurus griseus nigripes (south of San Francisco Bay to San Luis Obispo, California), and Sciurus griseus anthonyi (northwestern Baja California, México, to south-central California) (Hall 1981, Bayrakci et al. 2001). The third subspecies is known to occur as far south as Sierra Juárez, nearly 64 km south of México’s international border with the United States (Mellink and Contreras 1993).

At elevations above $1500 \mathrm{~m}$, the western gray squirrel occurs in habitats composed of oaks (Quercus douglasii and Quercus dumosa), conifers (Pinus sabiniana, Pinus ponderosa, and Pinus lambertiana), and riparian trees such as Platanus recemosa and Populus fremontii. At elevations below $1500 \mathrm{~m}$, this species prefers stands of American walnut (Juglans sp.) (Ingles 1947). In suburban and urban areas of southern California, the western gray squirrel is being replaced by the introduced eastern fox squirrel (Sciurus niger) (Muchlinski et al. 2009).

Several specimens of $S$. g. anthonyi have been collected in Baja California. Huey (1964) reported the first specimen, which was collected in the Sierra Juárez near the Rancho El Rayo $\left(32^{\circ} 00^{\prime} \mathrm{N}, 115^{\circ} 57^{\prime} \mathrm{W}\right)$ and deposited in the Mammals Collection of the San Diego Natural History Museum (SDNHM-11893). An additional 11 specimens $\left(8\right.$ 우, 3 oै $\sigma^{\hat{*}}$ ) were collected at Laguna Hanson on the Sierra Juárez in May and August 1979 and deposited in the Museum of Southwestern Biology, University of New Mexico (MSB Mammals 40346-40348, 4093340940). Mellink and Contreras (1993) published a record of western gray squirrel for Baja California on the basis of a male collected by Gorgonio Ruiz-Campos (GRC) in Laguna Hanson (1 km south of Quinta Patricia; $32^{\circ} 02^{\prime} \mathrm{N}, 115^{\circ}$ $56^{\prime} \mathrm{W}$; Fig. 1) and deposited in the Mammals Collection of the Universidad Autónoma de Baja California (CVUABC-114). Two other specimens were also collected by GRC in Laguna Hanson $\left(32^{\circ} 3^{\prime} 26.4^{\prime \prime} \mathrm{N}, 115^{\circ} 54^{\prime} 01.9^{\prime \prime} \mathrm{W}\right)$ on 11 January 2002 (1 q) and 4 March 2006 (1 ô). Measurements $(\mathrm{mm})$ for the female specimen (CVUABC108) were total length (TL) 561, tail length (CL) 250, hind foot length (HFL) 70.5, ear length (EL) 28.7, interorbital breadth (IB) 19.8, zigomatic breadth (ZB) 35.9, and length of upper molar row (UPL) 12.3. Measurements for the male specimen (CVUABC-122) were TL 600, CL 255, HFL 690, and EL 28.

On 21 May 2009, we found a dead male S. g. anthonyi $16 \mathrm{~km}$ north of Cataviña, Baja California $\left(29^{\circ} 50^{\prime} 59.72^{\prime \prime} \mathrm{N}, 114^{\circ} 49^{\prime} 42.24^{\prime \prime} \mathrm{W}\right)$.

${ }^{1}$ Facultad de Ciencias, Universidad Autónoma de Baja California, AP. 233, Ensenada, Baja California 22800, México.

2E-mail: jonas286@hotmail.com 


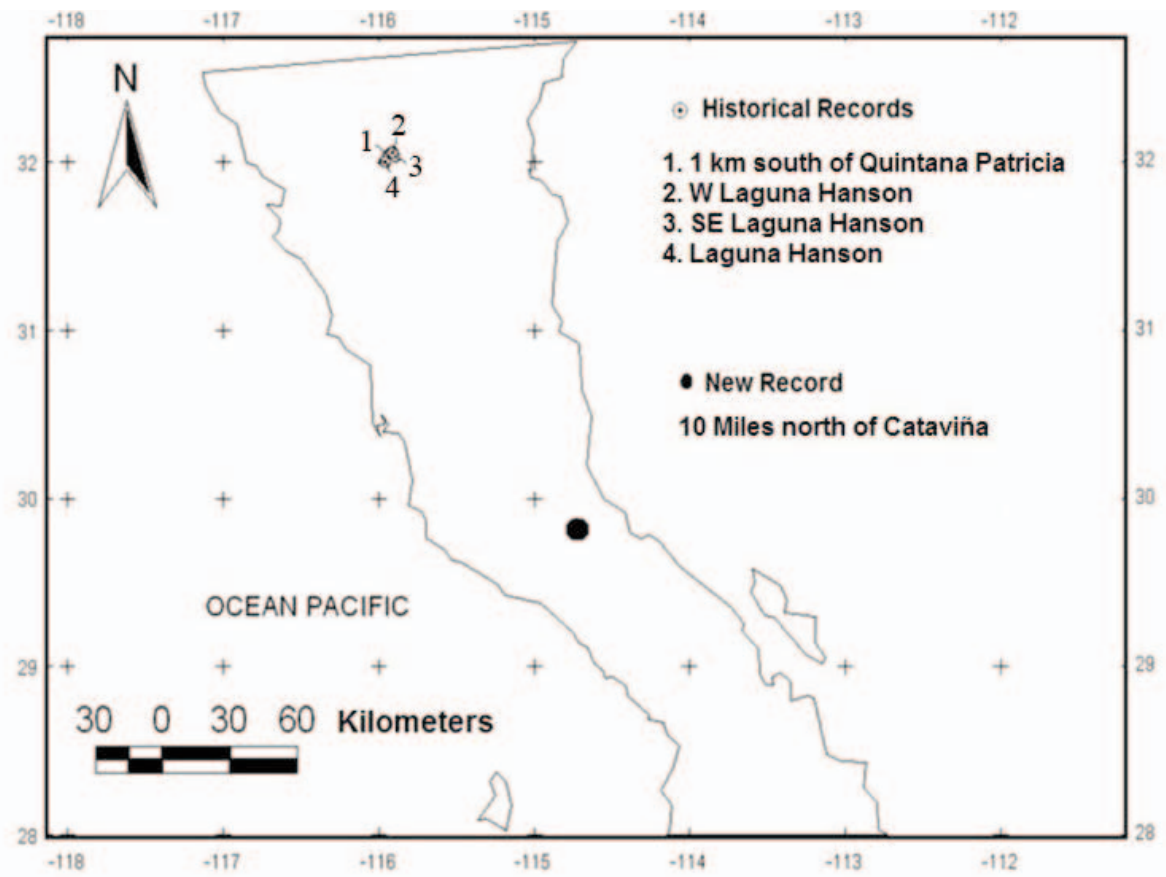

Fig. 1. Historical records and the southernmost record for Sciurus griseus anthonyi in the state of Baja California, México.

This specimen was deposited in the collection referred to above (CVUABC-903) and has the following body measurements (mm): TL 590, CL 255, HFL 71, EL 32, IB 20.4, ZB 36.0, and UPL 12.84.

The previous historical records for the distribution of S. g. anthonyi in Baja California (Fig. 1) come from sites in or near the Constitución 1857 National Park, where vegetation is dominated by conifers (Pinus jeffreyi). However, the new specimen reported here was collected near the town Cataviña, nearly $258 \mathrm{~km}$ south of the previous locations. The habitat surrounding the collection location was transition vegetation composed of Mediterranean chaparral and desert scrub elements (Delgadillo 1998). Several individuals of this subspecies were detected in this same location (15 April 2010), which might suggest the presence of a marginal population. The lack of intensive exploration of mammals in the region between Cataviña and the southern portion of the Sierra San Pedro Mártir makes it difficult to determine whether or not the new record of $S$. $g$. anthonyi resulted from a recent range expansion.

\section{LITERATURE CITED}

BaYRaKCI, R.T., A.B. CareY, AND T. Wilson. 2001. Current status of the western gray squirrel population in the Puget Trough, Washington. Northwest Science 75: 333-341.

Delgadillo, R.J. 1998. Florística y ecología del norte de Baja California. Universidad Autónoma de Baja California, Mexicali. 407 pp.

HaLL, E.R. 1981. The mammals of North America. 2nd edition. John Wiley \& Sons, New York, NY. 1181 pp.

Huey, L.M. 1964. Mammals of Baja California, México. Transactions of the San Diego Society of Natural History 13:85-168.

INGLES, L.G. 1947. Ecology and life history of the California gray squirrel. California Fish and Game Bulletin 33: 139-157.

MeLlinK, E., and J. Contreras. 1993. Western gray squirrels in Baja California. California Fish and Game 79: 169-170.

Muchlinski, A.E., G.R. Stewart, J.L. King, and S.A. LEWIS. 2009. Documentation of replacement of native western gray squirrels by introduced eastern fox squirrels. Bulletin of the Southern California Academy of Sciences 108:160-162.

Received 13 May 2010 Accepted 11 October 2010 